\title{
UJI AKTIVITAS ANTIOKSIDAN EKSTRAK DAUN SIRIH HITAM (Piper sp.) TERHADAP DPPH (1,1-DIPHENYL-2-PICRYL HYDRAZYL)
}

\author{
Nazmy Maulidha*, Aditya Fridayanti, Muhammad Amir Masruhim \\ Laboratorium Penelitian dan Pengembangan FARMAKA TROPIS, Fakultas Farmasi, Universitas Mulawarman, \\ Samarinda, Kalimantan Timur \\ *email: nazmyfarmasi@yahoo.com
}

\begin{abstract}
ABSTRAK
Aktivitas antioksidan daun sirih hitam (Piper sp.) telah diuji menggunakan DPPH $(1,1$ diphenyl-2-picrylhydrazyl). Penelitian ini bertujuan untuk mengetahui aktivitas antioksidan dari ekstrak dan fraksi daun sirih hitam. Ekstrak yang digunakan dalam penelitian ini adalah ekstrak kasar dan ekstrak fraksi dengan berbagai pelarut, yakni metanol, $n$-heksana, etil asetat, dan n-butanol. Penelitian ini menggunakan metode peredaman radikal bebas DPPH dan absorbansi diukur pada spektrofotometer $U V$-Visible selanjutnya ditentukan nilai $\mathrm{IC}_{50}$ dengan menggunakan analisis regresi linier. Dari hasil penelitian menunjukkan bahwa ekstrak yang memiliki aktivitas antioksidan adalah ekstrak metanol dengan nilai $\mathrm{IC}_{50} 158,53 \mathrm{ppm}$, ekstrak fraksi etil asetat dengan nilai $\mathrm{IC}_{50} 165,46 \mathrm{ppm}$, dan ekstrak fraksi n-butanol dengan nilai $\mathrm{IC}_{50}$ 172,74 ppm. Hasil ini menunjukkan bahwa ekstrak dan fraksi daun sirih hitam memiliki aktivitas antioksidan yang lemah.
\end{abstract}

Kata Kunci : Daun Sirih Hitam, Antioksidan, DPPH

\section{PENDAHULUAN}

Sirih hitam merupakan salah satu jenis dari tanaman sirih yang memiliki banyak pemanfaatan sebagai obat. Daun sirih hitam memiliki ciri khusus yakni bentuk daun menyerupai hati, bertangkai, daun berwarna hijau tua kehitaman dan bila dipegang daun terasa tebal dan kaku. Penggunaan empiris daun sirih hitam yang berhubungan dengan antioksidan adalah daun sirih hitam digunakan dalam pengobatan diabetes melitus.

Penyakit diabetes mellitus merupakan salah satu penyakit degeneratif yang diakibatkan radikal bebas menyerang asam lemak tak jenuh dalam jaringan sel sehingga terjadi reaksi antar sel dan menghasilkan senyawa peroksida yang merusak sel. Pada penderita diabetes melitus, meningkatnya kadar glukosa dalam darah disebabkan oleh kerusakan pankreas sehingga tidak dapat menghasilkan insulin, kerusakan pankreas ini dapat disebabkan oleh senyawa radikal bebas yang merusak sel-sel pada pankreas sehingga tidak dapat berfungsi (Purboyo, 2009).

Metabolit sekunder ekstrak daun sirih hitam teridentifikasi golongan senyawa alkaloid, flavonoid, tanin, saponin, senyawa fenol, karotenoid, dan steroid (Hastuty, 2011). Senyawa yang memiliki sifat sebagai antioksidan kuat yakni flavonoid, tannin, fenol, alkaloid, dan saponin (Heinrich, Joanne, Simon, dan Elizabeth, 2008).Terdapat beberapa kriteria suatu senyawa dikatakan memiliki aktivitas antioksidan yakni, Molyneux (2004) menyatakan bahwa suatu zat mempunyai sifat antioksidan bila nilai $\mathrm{IC}_{50}$ kurang dari 200 ppm. Bila nilai $\mathrm{IC}_{50}$ yang diperoleh 
berkisar antara 200-1000 ppm, maka zat tersebut kurang aktif namun masih berpotensi sebagai zat antioksidan (BrandWilliams, 1995). Secara spesifik, suatu senyawa dikatakan sebagai antioksidan sangat kuat jika nilai $\mathrm{IC}_{50}$ kurang dari 50 $\mu \mathrm{g} / \mathrm{mL}$, kuat untuk $\mathrm{IC}_{50}$ bernilai $50-100$ $\mu \mathrm{g} / \mathrm{mL}$, sedang jika $\mathrm{IC}_{50}$ bernilai $101-150$ $\mu \mathrm{g} / \mathrm{mL}$, dan lemah jika $\mathrm{IC}_{50}$ bernilai 151$200 \mu \mathrm{g} / \mathrm{mL}$ (Mardawati, Achyar, Marta, dan Herlina. 2008). Berdasarkan uraian di atas tentang metabolit sekunder yang terkandung dalam daun sirih hitam, dan khasiat daun sirih hitam dalam pengobatan diabetes melitus, maka dilakukan penelitian untuk mengetahui aktivitas daun sirih hitam sebagai antioksidan dengan menggunakan DPPH (1,1-diphenyl-2picrylhydrazyl) sebagai radikal bebas.

\section{METODE PENELITIAN}

\section{Bahan}

Daun sirih hitam (Piper sp.), air suling, metanol, $n$-heksana, etil asetat, $n$-butanol, dan pereaksi DPPH (1,1-diphenyl-2picrylhydrazyl).

\section{Alat}

Timbangan digital, spektrofotometer $U V$ Visible, kuvet, gelas kimia, labu ukur, batang pengaduk, botol timbang, mikro pipet $10-100 \mu \mathrm{L}$ dan $100-1000 \mu \mathrm{L}$, toples kaca, corong, water bath, rotary evaporator dan desikator.

\section{Prosedur Penelitian Antioksidan Ekstrak Daun Sirih Hitam}

Ekstrak daun sirih hitam yang digunakan adalah ekstrak metanol, ekstrak fraksi $n$ heksan, ekstrak fraksi etil asetat, dan ekstrak fraksi $n$-butanol. Masing-masing ekstrak dibuat dalam 5 variasi konsentrasi dengan menggunakan pelarut metanol. Selanjutnya dilakukan pembuatan pereaksi DPPH dengan konsentrasi $40 \mathrm{ppm}$. Ke dalam $2 \mathrm{~mL}$ ekstrak dimasukkan $2 \mathrm{~mL}$ larutan DPPH 40 ppm dalam tabung reaksi bertutup. Campuran larutan ini dihomogenkan dengan menggunakan vortex dan dibiarkan ditempat gelap pada suhu kamar selama 30 menit. Kemudian diukur absorbansinya pada panjang gelombang maksimum DPPH yang telah diperoleh pada penentuan panjang gelombang maksimum DPPH pada rentang 510-520 nm dengan menggunakan alat Spektrofotometer $U V$-Visible.

\section{HASIL DAN PEMBAHASAN}

\section{Ekstrak Metanol Daun Sirih Hitam}

Ekstrak metanol daun sirih hitam diperoleh dari proses maserasi dengan pelarut metanol. Konsentrasi yang digunakan pada pengujian aktivitas antioksidan ekstrak metanol ini adalah 50, 100, 200, 300, dan $400 \mathrm{ppm}(\mu \mathrm{g} / \mathrm{mL})$. Dari penelitian ini, diperoleh nilai absorbansi dan persen aktivitas antioksidan dari tiap konsentrasi yang ditunjukkan pada Tabel 1 .

Tabel 1 Nilai Absorbansi dan Persen Aktivitas Antioksidan Ekstrak Metanol Daun Sirih Hitam

\begin{tabular}{cccc}
\hline Konsentrasi (ppm) & Absorbansi & Persen aktivitas antioksidan (\%) & IC $_{\mathbf{5 0}}(\mathbf{p p m})$ \\
\hline Kontrol DPPH & 0,539 & - & \\
50 & 0,320 & 40,62 & \\
100 & 0,283 & 47,49 & 158,53 \\
200 & 0,252 & 53,18 & \\
300 & 0,232 & 60,22 & \\
400 & 0,169 & 68,70 & \\
\hline
\end{tabular}


Berdasarkan data pada Tabel 1, didapatkan persamaan regresi linier, yaitu $\mathrm{y}=0,075 \mathrm{x}$ $+38,11$. Dari persamaan regresi ini, maka diperoleh nilai $\mathrm{IC}_{50}$ ekstrak metanol daun sirih hitam sebesar 158,53 ppm. Berdasarkan hasil perhitungan ini, maka diketahui bahwa ekstrak metanol daun sirih hitam memiliki sifat sebagai antioksidan yang lemah karena nilai $\mathrm{IC}_{50}$ antara 150 200 ppm.

Dari Tabel 1, tampak terlihat semakin tinggi konsentrasi, maka semakin rendah absorbansinya. Hal ini dikarenakan semakin tinggi konsentrasi ekstrak, maka semakin tinggi pula kandungan zat antioksidannya, sehingga semakin banyak partikel DPPH yang akan dihambat oleh ekstrak tersebut dan semakin sedikit partikel DPPH yang tersisa, sehingga nilai absorbansi semakin kecil.

\section{Ekstrak Fraksi $n$-heksana Daun Sirih Hitam}

Ekstrak fraksi $n$-heksana daun sirih hitam diperoleh dari proses fraksinasi ekstrak metanol. Konsentrasi yang digunakan pada pengujian aktivitas antioksidan ekstrak fraksi $n$-heksana ini adalah 50, 100, 200, 300, dan $400 \mathrm{ppm}(\mu \mathrm{g} / \mathrm{mL})$. Dari penelitian ini, diperoleh nilai absorbansi dan persen aktivitas antioksidan dari tiap konsentrasi yang ditunjukkan pada Tabel 2 .

Tabel 2 Nilai Absorbansi dan Persen Aktivitas Antioksidan Ekstrak Fraksi n-heksana Daun Sirih Hitam

\begin{tabular}{cccc}
\hline Konsentrasi (ppm) & Absorbansi & Persen aktivitas antioksidan (\%) & IC $_{\mathbf{5 0}}(\mathbf{p p m})$ \\
\hline Kontrol DPPH & 0,541 & - & \\
50 & 0,427 & 21,01 & 249,38 \\
100 & 0,373 & 30,99 & \\
200 & 0,316 & 41,52 & \\
300 & 0,253 & 53,11 & \\
400 & 0,132 & 75,53 & \\
\hline
\end{tabular}

Berdasarkan data pada Tabel 2, didapatkan persamaan regresi linier ekstrak, yaitu $\mathrm{y}=$ $0,145 x+13,84$. Dari persamaan regresi ini, maka diperoleh nilai $\mathrm{IC}_{50}$ ekstrak fraksi $n$ heksana daun sirih hitam sebesar 249,38 ppm. Berdasarkan hasil perhitungan ini, maka diketahui bahwa ekstrak fraksi $n$ heksana daun sirih hitam tidak memiliki sifat sebagai antioksidan karena nilai $\mathrm{IC}_{50}$ ekstrak berada lebih dari dari 200 ppm. Aktivitas antioksidan ekstrak fraksi $n$ heksana lebih rendah jika dibandingkan dengan aktivitas antioksidan ekstrak metanol daun sirih hitam. Hal ini diperkirakan karena jenis senyawa dalam ekstrak fraksi $n$-heksana yang bersifat sebagai antioksidan telah mengalami pengelompokkan senyawa berdasarkan sifat kelarutannya pada proses fraksinasi.

\section{Ekstrak Fraksi Etil Asetat Daun Sirih Hitam}

Ekstrak fraksi etil asetat daun sirih hitam diperoleh dari proses fraksinasi ekstrak metanol. Konsentrasi yang digunakan pada pengujian aktivitas antioksidan ekstrak fraksi etil asetat ini adalah 20, 40, 80, 160, dan $320 \mathrm{ppm}(\mu \mathrm{g} / \mathrm{mL})$. Dari penelitian ini, diperoleh nilai absorbansi dan persen aktivitas antioksidan dari tiap konsentrasi yang ditunjukkan pada Tabel 3.

Tabel 3 Nilai Absorbansi dan Persen Aktivitas Antioksidan Ekstrak Fraksi Etil Asetat Daun Sirih hitam

\begin{tabular}{cccc}
\hline Konsentrasi (ppm) & Absorbansi & Persen aktivitas antioksidan (\%) & IC $_{\mathbf{5 0}}(\mathbf{p p m})$ \\
\hline Kontrol DPPH & 0,572 & - & 165,46
\end{tabular}




$\begin{array}{ccc}20 & 0,400 & 30,07 \\ 40 & 0,364 & 36,42 \\ 80 & 0,329 & 42,54 \\ 160 & 0,296 & 48,19 \\ 320 & 0,141 & 68,65\end{array}$

Berdasarkan data pada Tabel 3, didapatkan persamaan regresi linier ekstrak, yaitu $\mathrm{y}=$ $0,119 x+30,31$. Dari persamaan regresi ini, maka diperoleh nilai $\mathrm{IC}_{50}$ ekstrak fraksi etil asetat daun sirih hitam sebesar 165,46 ppm. Berdasarkan hasil perhitungan ini, maka diketahui bahwa ekstrak fraksi etil asetat daun sirih hitam memiliki sifat sebagai antioksidan yang lemah karena nilai $\mathrm{IC}_{50}$ ekstrak berada pada $150-200$ ppm. Aktivitas antioksidan ekstrak fraksi etil asetat lebih rendah jika dibandingkan dengan aktivitas antioksidan ekstrak metanol daun sirih hitam dan lebih tinggi jika dibandingkan dengan ekstrak fraksi nheksana. Hal ini diperkirakan karena jenis senyawa dalam ekstrak fraksi etil asetat yang bersifat sebagai antioksidan telah mengalami pengelompokkan senyawa berdasarkan sifat kelarutannya pada proses fraksinasi.

\section{Ekstrak Fraksi $n$-butanol Daun Sirih Hitam}

Ekstrak fraksi $n$-butanol daun sirih hitam diperoleh dari proses fraksinasi ekstrak metanol. Konsentrasi yang digunakan pada pengujian aktivitas antioksidan ekstrak fraksi $n$-butanol adalah 50, 100, 200, 300, dan $400 \mathrm{ppm}(\mu \mathrm{g} / \mathrm{mL})$. Dari penelitian ini, diperoleh nilai absorbansi dan persen aktivitas antioksidan dari tiap konsentrasi yang ditunjukkan pada Tabel 4 .

Tabel 4 Nilai Absorbansi dan Persen Aktivitas Antioksidan Ekstrak Fraksi n-butanol Daun Sirih Hitam

\begin{tabular}{cccc}
\hline Konsentrasi (ppm) & Absorbansi & Persen aktivitas antioksidan (\%) & IC $_{\mathbf{5 0}}(\mathbf{p p m})$ \\
\hline Kontrol DPPH & 0,564 & - & \\
50 & 0,378 & 32,98 & \\
100 & 0,335 & 40,54 & 172,74 \\
200 & 0,249 & 55,79 & \\
300 & 0,191 & 66,08 & \\
400 & 0,114 & 79,67 & \\
\hline
\end{tabular}

Berdasarkan data pada Tabel 4, didapatkan persamaan regresi linier ekstrak, yaitu y = $1,131 x+27,37$. Dari persamaan regresi ini, maka diketahui konsentrasi ekstrak fraksi $n$-butanol yang dapat menghambat $50 \%$ DPPH adalah sebesar 172,74 ppm. Berdasarkan hasil perhitungan ini, maka diketahui bahwa ekstrak fraksi $n$-butanol daun sirih hitam memiliki sifat sebagai antioksidan yang lemah karena nilai $\mathrm{IC}_{50}$ ekstrak berada antara 150-200 ppm. Aktivitas antioksidan ekstrak fraksi $n$ butanol lebih rendah jika dibandingkan dengan aktivitas antioksidan ekstrak metanol dan ekstrak fraksi etil asetat daun sirih hitam namun lebih tinggi dibandingkan ekstrak fraksi n-heksana. Hal ini diperkirakan karena jenis senyawa dalam ekstrak fraksi $n$-butanol yang bersifat sebagai antioksidan telah mengalami pengelompokkan senyawa berdasarkan sifat kelarutannya pada proses fraksinasi.

\section{KESIMPULAN}

Ekstrak daun sirih hitam memiliki aktivitas sebagai antioksidan yang ditunjukkan pada ekstrak metanol, ekstrak fraksi etil asetat dan ekstrak fraksi $n$ - 
butanol, ekstrak daun sirih hitam yang tidak memiliki aktivitas sebagai antioksidan ditunjukkan pada ekstrak fraksi $n$-heksana, dan nilai $\mathrm{IC}_{50}$ paling baik ditunjukkan pada ekstrak metanol yakni $158,53 \mathrm{ppm}$.

\section{DAFTAR PUSTAKA}

1. Brand-Williams, W.; Cuvelier, M.E.; \& Berset, C. 1995. Use of a Free Radical Method to Evaluate Antioxidant Activity. Lebensmittelwissenschaft und Technologie.

2. Hastuty, R. K. 2011. Identifikasi Metabolit Sekunder dan Uji Toksisitas dengan Metode Brine Shrimp Lethality Test (BSLT), Skripsi. Samarinda. Fakultas Farmasi-Universitas Mulawarman.

3. Heinrich, M.; Barnes, J.; Gibbsons, S.; \& Elizabeth, M. W. 2008.
Farmakognosi dan Fitoterapi. Penerbit Buku Kedokteran EGC : Jakarta.

4. Mardawati, E. C. S.; Achyar, M.; \& Herlina. 2008. Kajian Aktivitas Antioksidan Ekstrak Kulit Manggis (Garcinia mangostana L) dalam Rangka Pemanfaatan Limbah Kulit Manggis di Kecamatan Puspahiang Kabupaten Tasikmalaya. Fakultas Teknologi Industri PertanianUniversitas Padjajaran : Bandung

5. Molyneux, P. 2004. The use of the stable free radical diphenylpicrylhydrazyl (DPPH) for estimating antioxidant activity. Songklanakarin J. Sci. Technol.

6. Purboyo, A. 2009. Efek Antioksidan Ekstrak Etanol Daun Jambu Biji (Psidium Guajava L.) pada Kelinci Yang Dibebani Glukosa. Fakultas Farmasi-Universitas Muhammadiyah: Surakarta. 